observing stations. The Division of Radiation and Organisms has continued its work on the factors that influence the change in rates of respiration in plants. The study of the relation between light intensity and inhibition of growth of the oat mesocotyl was extended to higher intensities. Work is in progress on the isolation and separation of two pigments which occur in dark-grown oat seedlings. Since October 1942 the Division has done war work only.

\section{Regional Boundaries in Great Britain}

THE Association for Planning and Regional Reconstruction has issued a broadsheet dealing with the regional boundaries of England and Wales. This is of particular interest at the present moment, for it includes a series of maps, the first of which shows the civil defence regions related to a composite of boundaries comprising those of the Ministry of Labour and National Service, the Ministry of Transport, the Ministry of Food, the Board of Education Inspectorate, the Home Office Factory Inspectorate, and the Ministry of Works Contractors Regions, the Ministry of Agriculture Advisory Provinces and Statistical Divisions, the Board of Trade Census of Production 1935 areas, those for the Registrar-General for the Census, and the Post Office regions. The five remaining maps show the divisions suggested by Prof. C. B. Fawcett in 1942, Mr. John Dower in 1938, Mr. E. W. Gilbert in 1941, Prof. E. G. R. Taylor in 1941, and Mr. E. A. A. Rowse in 1941, respectively.

\section{Vitamin Content of Brazilian Foods}

According to the Journal of the American Medical Association of February 20, Dr. Moura Campos, professor of physiology at the University of São Paulo, is conducting a series of researches on the vitamin content of Brazilian foods and on the practical importance of the different vitamins. In a recent paper he showed that thiamine and riboflavin act in association to help in the utilization of the food material by stimulation of the appetite and increase in the assimilation of food. His experiments prove that the presence of thiamine is necessary to the utilization of riboflavin. Thiamine alone cannot maintain the growing capacity. Mandioquinha (Chorophyllum bulbosum) contains riboflavin but not thiamine, while goiaba (Psidium guajava) contains both thiamine and riboflavin. Experiments showed that the growth of rats was well maintained when they were fed. on goiaba alone.

\section{Earthquakes Registered in Spain}

DuRING January 1943 ten earthquakes were registered by the seismographs at Toledo, Spain (Registro de las observaciones provisionales correspondientes al mes de Enero de 1943. Instituto Geografico. Observatorio Geofisico de Toledo). Eight of these shocks were distant, some being rather feebly recorded and somewhat obscured by microseisms. The shock of January 7 recorded at $11 \mathrm{~h} .19 \mathrm{~m}$. $01 \mathrm{~s}$., from an epicentre some $4,445 \mathrm{~km}$. distant, had a probable depth of focus of $100 \mathrm{~km}$. Two shocks were somewhat local. The first, on January 9, began recording with $i P z$ at $22 \mathrm{~h}$. $00 \mathrm{~m}$. $19 \mathrm{~s}$. from an epicentre some $318 \mathrm{~km}$. distant and a depth of focus of $25 \mathrm{~km}$. The epicentre was most likely in the Sierra Tejada. The second, on January 21, began recording with $e P z$ at $14 \mathrm{~h} .47 \mathrm{~m} .17 \mathrm{~s}$. from an epicentre some $344 \mathrm{~km}$. distant from Toledo and a depth cf focus of $40 \mathrm{~km}$. The epicentre was probably in the neighbourhood of Novelda-Monforte.

\section{Institution of Electrical Engineers: Premium Awards}

THE Council of the Institution of Electrical Engineers has made the following awards of premiums : Institution Premium : C. J. Beaver and E. L. Davey ; Kelvin Premium: Dr. F. Brailsford and R. G. Martindale; John Hopkinson Premium: Mr. R. A. W. Connor ; Non-Section Premiums : Dr. E. Friedlander (Ayrton Premium), Mr. C. T. Melling (Llewellyn B. Atkinson Premium), Mr. J. Swaffield (extra premium); Wireless Section Premiums: Dr. R. L. Smith-Rose and Miss A. C. Stickland (Duddell Premium), G. Parr and W. Grey Walter (Ambrose Fleming Premium), Prof. Willis Jackson (extra premium); Measurements Section Premiums : Lieut.Col. K. Edgcumbe (Silvanus Thompson Premium), M. Kaufmann and W. Szwander (Mather Premium), G. H. Barker and A. L. Hancock (extra premium); Transmission Section Premiums: A. W. Thompson and J. C. Wood-Mallock (Sebastian de Ferranti Premium), A. A. Pollitt (John Snell Premium), H. Willott Taylor and K. L. May (extra premium); Installations Section Premiums: G. B. Alvey and N. Tetlow (Crompton Premium), Forbes Jackson, W. J. H. Wood, G. Smith and E. Jacobi (Swan Premium), J. R. Taylor and C. E. Randall (extra premium); Paris Exhibition, 1881, Premium: J. N. Waite.

\section{Physical Society: Officers for 1943-44}

AT the annual general meeting of the Physical Society held on May 18, the following officers were elected for the year 1943-44: President: Prof. E. N. da C. Andrade; Vice-Presidents : Dr. J. H. Brinkworth, Prof. C. D. Ellis, Dr. H. T. Flint, Prof: N.F. Mott; Treasurer : Dr. C.C.Paterson; Secretaries: Mr. J. H. Awbery (Papers), Dr. W. Jevons (Business); Foreign Secretary : Sir Owen Richardson ; Librarian: Prof. L. C. Martin; New Members of Council: Prof. D. Brunt, Dr. B. Chalmers, Brigadier B. F. J. Schonland, Dr. W. S. Stiles. The chairman and secretary of the Colour Group are Mr. J. Guild and Mr. H. D. Murray, respectively; and of the Optical Group, Dr. A. O. Rankine and Prof. L. C. Martin.

\section{Announcements}

THE Copernicus Quatercentenary Celebration Committee has arranged a meeting, to be held at the Royal Institution on May 24 at 3.30 p.m, in honour of Nicolaus Copernicus. The meeting will be opened by Sir Henry Dale, and addresses will be given by Prof. Stanisław Kot, Polish Minister of Information, and Dr. H. Spencer Jones.

The Council of the University of Sheffield has made the following appointments : J.T. Chesterman to be lecturer in surgical pathology and assistant curator of the Museum; Dr. John Sinclair to be lecturer in mining; and T. F Bamber to be research assistant in mining.

THE following appointments have recently been made in the Colonial Service: S. B. Kendall, veterinary officer, Tanganyika; R. K. J. Gascoigne, entomologist, Sleeping Sickness Control Service, Nigeria, to be agricultural officer, Nigeria; Dr. G. N. A. Hall, veterinary pathologist, Gambia, to be veterinary adviser, Sierra-Leone and Gambia (jointly). 